DOI 10.31558/2519-2949.2019.1.8

УДК 321.01:316.32

ORCID ID: https://orcid.org/0000-0002-0295-5332

Хилько М. І., Київський національний університет імені Тараса Шевченка

\title{
ЕКОЛОГІЧНА КРИЗА ЯК КРИЗА ІСНУЮЧОЇ СИСТЕМИ ЦННОСТЕЙ
}

З'ясовано, щуо сучасна екологічна криза має глибокі сочіально-економічні корені але, головним чином ие - криза духовності. Ідея всеосяжного контролю над природою є плодом зарозумілості і невиправданої засміченості свідомості хибними ідеями, щз природа існує лише для комфорту людини.

Виявлено одну з найістотніших суперечностей, щзо значною мірою виражає сутність екологічної проблеми - суперечність між економічним поступом людства і можливостями біосфери до самовідновлення. Зазначається, щуо стратегія практичних орієнтацій призвела до споживацтва, виснаження природних ресурсів і деградації природи. Акиентується увага на особливій небезпеці явища споживацтва як: з економічної точки зору, оскільки природа не в змозі через обмеженість ї̈ ресурсів у кожний даний момент часу задовольнити нескінченні матеріальні потреби людини; з геополітичної- посилюється агресивність поведінки людей, народів і держав в умовах обмежених ресурсів; з молальноӥ-оскільки націленість на споживацтво так званих модних, престижних речей будь за веде до втрати.людиною розуміння цінності і изілісності природи, і як наслідок викривлене сталення до самої себе як особистості. Для такої людини чистота повітря, води, грунтів і лісів перестає бути цінністю, оскільки головними стають статок, престиж, гроші, інші подібні приваби. У цььому сенс примітивного споживацького підходу до життя і природи.

Робиться висновок, щу обмеженість сучасного людства в ресурсах-це результат дї певних сочіальних і культурних чинників, на які можна впливати через організацію суспільного життя. Вищі духовні иүінності повинні якось регулювати побутові потреби та їх диференціацію. Потрібне нове переосмислення місия людини у світобудові: розглядати людину не як завойовника природи, а як органічну ї̈ складову частину, тобто докорінно змінити иінності, насамперед ті, які регулюють ставлення людини до природи. Важливо усвідомити, щуо саме по собі зростання добробуту, поліпшення умов існування ще не робить людей щзасливими. Сучасній людині потрібно вгамувати свої традиційні раціонально-прагматичні пріоритети, суттєво підвищити рівень моральності й духовності, усвідомити, щзо в процессі природокористування здобувається не тільки «хліб насущиий», а й «хліб духовний». Пропонуються основні напрями зміни вектору економічного розвитку, так звані стратегічні екологічні ініціативи людства, які водночас були б основою зміни моральної парадигми розвику в якій економічним вважалося б тільки те, шуо є екологічним.

Ключові слова: екологічні цінності, екологічна криза, біосфера, споживацтво, природні ресурси, стратегічні екологічні ініціативи.

Постановка проблеми. Екологічна криза яка вразила людство значною мірою зумовлена пануючими в наш час системами цінностей. Кризові моменти у взаємовідносинах людини 3 природним середовищем виникають, як це не парадоксально, 3 посиленням технічної могутності людини. Суспільство продукує на природу свої як позитивні, так і негативні сторони і тим самим багато в чому визначає стан природних екосистем, динаміку їх змін. Однак, чи техніка й технології винні в різкому погіршенні екологічного стану. На наш погляд, сучасна екологічна криза має глибокі соціально-економічні корені i, головним чином це - симптом душевного i духовного неблагополуччя людини, криза духовності.

Аналіз останніх досліджень і публікацій. Загальновідомими політико-філософськими дослідженнями в яких автори ставили питання про необхідність перебудови сучасного суспільства в екологічне i шукали шляхи поєднання екологічних цінностей з демократизацією суспільних відносин є праці К. Алорі, Ф. Вестера, А. Гора, Б. Деволла, К. Траубе, Д. Формена, Е. Фрома, В. Хозенклевера та ін. В Україні аналізом проблем екологічної свідомості, екологічної освіти 
і культури досить плідно займаються В. Горлинський, А. Єрмоленко, М. Кисельов, В. Крисаченко, Г. Марушевський, Г. Науменко, Д. Топоровський та ін. Однак, спеціальних праць, присвячених ціннісним основам екологічно безпечного розвитку, за виключенням деяких публікацій В. Горлинського, все ще чекає наукова громадскість.

Мета статті - 3'ясувати чинники, які сприяють наростанню деградації планетарних екосистем та запропонувати для обговорення ймовірні стратегічні екологічні ініціативи по зміні вектора економічного розвитку.

Виклад основного матеріалу. Пройдений після Стокгольмської конференції (1972р.) шлях показав, що основні тенденції швидкого погіршення глобальних і регіональних екологічних умов не змінилися. Незважаючи на величезні капіталовкладення і у порівняно благополучних регіонах посилюються деформації навколишнього середовища: в Західній Європі, наприклад, розширюються площі уражених лісів, збільшуються території закисання грунтів і число забруднених водойм, зникають гриби і т.д. У межах існуючих стереотипів причину цього здебільшого шукають у недостатній природоохоронній господарській діяльності, хоча це, як відомо, лише одна 3 них.

Можна, правда, назвати і деякі локальні програми «очищення» навколишнього середовища, які виявились досить ефективними. Це, зокрема, проекти «Темза» (Англія), «Сена-Маас» (Франція), «Рейн» (Німеччина). $\mathcal{C}$ позитивний досвід реалізації і міжнародних програм таких, як, приміром, програма оздоровлення Великих американських озер. На жаль, таких програм не так багато і всі глобальні негативні тенденції не тільки збереглися, а й посилилися. Зазначимо, що абсолютно всі тенденції погіршення екологічної ситуації у світі властиві природному довкіллю й України, де квітучий і благодатний колись край перетворився в зону суцільного екологічного лиха. I причинами цього є не тільки соціально-економічні наслідки господарюванняя. А й, перш за все, світоглядні, ціннісні, культурні.

Що це так видно, хоча б, з такого прикладу. Переважна більшість людей ходить у ліс не для того, щоб слухати спів птахів і милуватися квітами, а по ягоди, гриби, на полювання. Можуть заперечити, що це, мовляв, потрібно, оскільки існують труднощі з продуктами харчування. Але таке пояснення далеко недостатнє, адже споживацтво поширене і в суспільствах, де продуктів вистачає. У принципі, скільки б людина не мала, вона завжди може хотіти більше.

Які екологічні наслідки цього? «По-перше, орієнтація на споживацтво призводить до виснаження і деградації природи. I, по-друге, посилюється агресивність поведінки людини в умовах обмежених ресурсів. Споживацтво небезпечне і з економічної точки зору, оскільки природа не в змозі через обмеженість ії ресурсів у кожний даний момент часу задовольнити нескінченні матеріальні потреби людини. Крім того, націлена на споживацтво так званих модних, престижних речей людина втрачає розуміння цілісності природи, цілісність ставлення до неї i слідом за тим цілісність самої себе як особистості. Для неї чистота повітря, води, грунтів і лісів перестає бути цінністю. Головне - достаток, гроші та інші подібні приваби. У цьому сенс примітивного споживацького підходу до життя і природи» [1. с. 126-127].

Тож необхідно змінити цінності, насамперед ті, які регулюють ставлення людини до природи. Важливо усвідомити, що саме по собі зростання добробуту, поліпшення умов існування ще не робить людей щасливими. I потрібно вгамувати свої традиційні раціонально-прагматичні пріоритети, суттєво підвищити рівень моральності й духовності. Стратегія практичних орієнтацій людства має суттєво змінитися, адже в процессі природокористування здобувається не тільки «хліб насущий», а й «хліб духовний». Природу не можна сприймати як комору, з якої людина бере в необмеженій кількості те, що ӥй потрібно, а повертає відходи своєї діяльності, до яких їй немає ніякого діла. Природа, звичайно, не храм, яким належить захоплюватись, але і не тільки майстерня, a джерело фізичного і духовного життя людини, неминуща цінність, що має для людського існування вирішальне значення [2, с.122,123].

На жаль, людина змушена була боротися з природою і приречена на боротьбу при всіх можливих способах виробництва. Тобто, єдність людини і природи досить суперечлива. Але це не означає, що цю суперечливість потрібно загострювати і надалі, наближаючи екологічну катастрофу i сподіваючись, що людина зможе адаптуватись до будь-яких змін. «Боротьба 3 природою, - як підкреслює А.Горєлов, - ніколи не скінчиться, але перемога над нею обертається для людини поразкою, оскільки сама людина - частина природи, а природа - початок, що породжує їі» [2, с.126].

Слід зауважити, що значне число жителів планети були «мічуринцями» і жили за принципом: «Ми не можемо чекати милостей від природи, взяти їх у неї - наше завдання». Взяти милість 
силою? Але ж саме прагнення якомога більше взяти і призвело до того, що нині дійсно вже не слід чекати милості від природи, адже ми в неї вже і так забагато взяли.

Людина віками і пристосовувалась і вела боротьбу зі стихійними силами природи. I ось нарешті вона вперше може ії знищити. Вже знищивши багато представників флори і фауни на Землі, людина переступила ту межу, за якою руйнуються основи існування активної частини природної системи в цілому та її окремих частин зокрема. Саме тому головним «стихійним лихом» і для природи і для людини стає вона саме. Споживач має стримувати себе, не забувати, що не можна постійно брати, не віддаючи, інакше звідки візьметься бажане? Загалом, $\epsilon$ всі підстави стверджувати, що обмеженість сучасного людства в ресурсах - це результат дії певних соціальних і культурних чинників, на які можна певною мірою впливати через організацію суспільного життя. Вищі духовні цінності повинні якось регулювати побутові потреби та їх диференціацію. Потрібне нове переосмислення місця людини у світобудові: розглядати людину не як завойовника природи, а як органічну її складову частину. Ідея всеосяжного контролю над природою є «плодом зарозумілості, що, - як стверджус Р. Карсон, - і народилася тоді коли біологія та філософія перебували на неандертальському рівні і коли вважалося, що природа існус лише для комфорту людини» [3, с.27].

Нині у всьому світі досить активно відбувається переорієнтація від настанови на «прискорення» науково-технічного прогресу до ідеології «виживання». На конференціях ООН з довкілля та розвитку (Ріо-де-Женейро, 1992 р., Йоганесбург, 2002 р.) всебічно обговорювалася проблема повороту нашої цивілізації на шлях розвитку, на якому людина буде змушена «вгамувати свій гонор та споживацький егоїзм» і відшукати ефективні засоби існування у злагоді з природою. Об'єктивна залежність траєкторії розвитку людства від стану природного довкілля була визнана одностайно всіма учасниками згаданих Конференцій.

По суті, це означає, що на перший план виходить пошук засобів розв'язання суперечностей між економічним поступом і збереженням довкілля, досягнення повної збалансованості між цими сферами. Ігнорування цієї єдності, забуття того, що не тільки виробництво, а й сама природа $€$ основою людської життєдіяльності - одна з гносеологічних і діяльнісних причин екокризи, що настає. Ось чому теза про сутнісну єдність економіки і екології, або як вона реалізується у виробництві чи в інших формах діяльності людей, є разом з тим наріжним каменем, на якому будуватиметься вирішення проблем довкілля.

Необхідно виправити ті вади економічної філософії, які індустріально розвинені країни спочатку легітимізували, а потім заохочували екологічну руйнацію. Йдеться про безумовну зміну економічних орієнтирів - за допомогою яких наша цивілізація - або, в крайньому разі, основна i зростаюча іiі частина, яка пов'язана з ринковою економікою, - оцінює свої рішення. «Глибока соціальна й екологічна криза сучасної цивілізації, - як справедливо підкреслюють І.Алексеєнко і Л.Кейсевич, - виникла головним чином з вини $є$ самої людини. Ініційована вона нею в ім'я досягнення своїх приватних, вузькоутилітарних цілей i задоволення любою ціною своїх всезростаючих потреб, із-за чого життя на Землі і само існування людства опинилось під загрозою» $[4$, c.9]. Споживацьке ставлення до природи призводить до іiі руйнації. Тому є очевидним, що «шлях сучасної цивілізації, що спирається на індустрію і неупинний економічний розвиток, є хибним. На ньому принципово неможливо досягти усталеного розвитку, якби ми не вдосконалювали систему природокористування. Йдучи по ньому, ми назавжди приречені йти за подіями і марно намагатися виправити наслідки наших власних руйнівних дій» [5, с.23].

Система всезагальної корисності - це та субстанційна основа, що об'єднує докупи всі часткові й особливі прояви людської цивілізації. У розвинених країнах нині живе всього $13 \%$ населення земної кулі, а його частка в забрудненні й руйнуванні природи становить $70 \%$. Такою є ціна високого рівня життя. Одна з відмінностей сучасного суспільства від того, яке було відоме К. Марксу, полягає в тому, що людина вже так жорстоко не експлуатується. Експлуатація ж природи стала ще більшою, по суті, граничною. У нерозвинених країнах і тих, що розвиваються, ставлення до природи таке саме - корисливе і руйнівне [23, с.26].

Таким чином, гонитва за технічними та економічними показниками $є$ загальнопланетарною тенденцією. Як справедливо зазначає М.Кисельов, скрізь «багатства живої природи, кращі здібності людини приносяться в жертву досягненню "високого життєвого рівня". Все буття людини, іiі ментальність і система цінностей поставлені виключно в економічну площину. В результаті складається досить абсурдна ситуація: прибутки зростають, підвищується нібито рівень життя, а стан навколишнього середовища i самопочуття людей стають дедалі гіршими. Гонитва 
за прибутками дається взнаки навіть у сфері екології: охорона природи розглядається як збереження ресурсів для промисловості, а охорона того чи іншого виду ставиться в залежність від того, наскільки він є корисним» [5, с.23]. Усе це свідчить про те, що людство є хворим на іпохондрію. «Воно настільки сильно стурбоване своїм економічним станом, що втратило здатність лишатися здоровим» [3, с.47]. Разом 3 тим слід відзначити, що «наслідки руйнування людиною природи наступили не відразу, а згідно відомому принципу віддаленості подій лише тоді, коли збіднів видовий склад біосфери і в значній мірі вичерпались компенсаційні можливості їі восьми буферних систем - радіаційних поясів Землі, магнітосфери, озонового шару, атмосфери, грунтів, лісів, океанів і генофонду біосфери» [4, с.10].

Проте споживацтво не слід плутати зі споживанням - задоволенням потреб, які відповідають внутрішній природі людини і без яких саме життя людини неможливе. Споживацтво - це переважна спрямованість споживання на шкоду духовному життю, причому - нерідко пов'язане iз задоволенням псевдопотреб. Останні можуть бути двох видів: які перевищують реальні потреби, i такі, що заміняють їх (часто із-за неможливості задовольнити справжні) і мають свою внутрішню й зовнішню детермінанти. Одні пов'язані зі штучним формуванням потреб, інші - мають переважно психологічні властивості, хоча ті й інші кореняться в соціальній дисгармонії. А це додатковий соціальний тягар, який накладається на природу [2, с.121].

Відсутність цілісного погляду на природу як найпершу основу існування призвела до гіпертрофування природоперетворюючих можливостей людства, нехтуючи при цьому адаптивними, пристосувальними механізмами цивілізаційного процесу. Сталася величезна помилка - акцент на соціальному розвитку заслонив саму природу, відсунув іiі на другорядне місце. Реальний екорозвиток соціуму виявив одну з найістотніших суперечностей, що значною мірою виражає сутність екологічної проблеми - суперечність між необхідністю подальшого нарощування виробництва і можливостями біосфери, яка під впливом господарської діяльності, антропогенного тиску дедалі деградує, наближаючи світ до глобальної екологічної катастрофи.

Чи можна уникнути цієї катастрофи, не знижуючи, а навпаки прискорюючи розвиток продуктивних сил i, разом 3 тим, зберегти біосферу. Йдеться про можливість спільного розвитку двох вищих форм руху матерії на планеті. Цілком зрозуміло, що їх співіснування передбачає й наявність обмежень для цього спільного розвитку, пошук компромісних рішень, оскільки перекіс в один бік породжує негативні наслідки для обох форм руху матерії. Це свідчення того, що взаємодія суспільства і природи досягла такого рівня, коли вже видно риси спільної деградації, соціального і екологічного регресу. Тому термін «коеволюція», тобто спільна їх еволюція найкраще передає сутність поставленої проблеми. Коеволюція означає такий спрямований розвиток людського суспільства і його вплив на біосферу, які не тільки не руйнують біосферу, а сприяють їі подальшому розвитку і забезпеченню соціальному прогресу.

Інтернаціоналізація еколого-економічних відносин у світовому виробничому процесі породжує ряд проблем, які важко вирішити на цьому етапі розвитку цивілізації. Мається на увазі, зокрема, пошук методів міжнародного регулювання природокористування i міждержавних еколого-економічних відносин, що складаються тут. Всесвітня взаємозумовленість і взаємозалежність екологічних і економічних відносин вимагають їх глибокого аналізу, врахування та гармонізації. Всеохоплюючий міжнародний характер «глобалізації» ставить перед світовим співтовариством завдання регулювання як екологічних відносин, що виникають у системі «природа-суспільство», так і економічних. На сучасному етапі розвитку суто економічний або суто екологічний підходи до розвитку є неправомірними і мають бути замінені комплексним еколого-економічним підходом [7, с.127].

Необхідність регулювання соціоприродних відносин, хоча й визнається світовим співтовариством, проте і досі головним критерієм у природокористуванні є все ж економічність або валовий економічний критерій, що домінує у людському мисленні. Але це - глухий кут розвитку. Отже, традиційний загальноцивілізаційний підхід до економіко-екологічної політики вимагає значної модифікації, з урахуванням екологічних реалій.

Водночас усе це свідчить про те, що проблема збереження довкілля набула статусу важливої, навіть провідної економічної проблеми. Саме тому Міжнародне товариство з екологічної економіки, активними членами якого є десятки країн світу, визначає екологію як «господарство природи (natures household)», а економіку як «господарство людини (humankinds household)» і ставить на меті дослідження «екології людини» й «економіки природи», всієї межі взаємозв'язків, що включає економічну підсистему як частину, або невід'ємний складник глобальної екосистеми [8, с. 90-91]. 
До середини 80-х років екологічна політика стосовно скорочення техногенного впливу на навколишнє середовище в багатьох країнах будувалася на визнанні пріоритету адміністративноправових заходів. Одним з позитивних результатів цього було створення структури державних органів і громадських організацій, у функції яких входить забезпечення природоохоронної діяльності від місцевого до національного рівнів. Крім того, створені основи національних систем екологічного права, стандартів та нормативних актів, що регламентують різні види діяльності господарських суб'єктів i фізичних осіб за критеріями екологічної безпеки. Цей напрямок в екологічній діяльності постійно вдосконалюється, хоча ефективність заходів дещо знизилась. Причина - увідсутності стимулюючої природоохоронної мотивації за орієнтації тільки на адміністративно-правові заходи. Ось чому в методології національних екологічних політик основна увага приділяється економічним методам, що стимулюють оптимальне використання навколишнього середовища. Складність реалізації таких методів для практичних цілей полягає в подоланні суб'єктивізму при визначенні вартості як негативних впливів так і компенсуючих заходів.

У цілому використання економічних механізмів, як засобу природоохоронної політики, показало їх значну ефективність, незважаючи на те, що в тлумаченні самих принципів економічного регулювання $є$ суперечності, які ще не вирішені. Було б добре, звичайно, якби в економічних рішеннях враховувались екологічні критерії. Шкода, але урядовці й немало політиків, схоже, не від того, щоб звалити екологічні наслідки економічних рішень у великий кошик для сміття з етикеткою «зовнішні обставини», під якими мається на увазі все те, що економісти хотіли б забути.

Існуючий підхід до економічної політики повинен змінитися, якщо людство збирається забезпечити стійкий розвиток земної цивілізації. Світовим лідерам і міністрам економіки слід скликати зустріч у верхах для обговорення стратегічного завдання - зміни вектора економічного розвитку. Йдеться про прийняття без зволікання цілого комплексу нових державних і міждержавних економічних орієнтирів. Такими можуть бути наступні:

1. Держави мають наполягати навключення норм захисту навколишнього середовища вміжнародні договори $i$ угоди, в тому числі торгівельні (зокрема норм екологічної відповідальності). Екологічні стандарти слід прирівняти до тих критеріїв, згідно з якими здійснюється лібералізація торгових угод, насамперед тому, що розвинені країни прагнуть розширити принципи вільного ринку і налагодити вільну торгівлю з рештою світу. Захист навколишнього середовища і комерційні переговори - це надто нестійка суміш. Потрібні дуже жорсткі екологічні стандарти (наприклад, ті, що пропонує Німеччина запровадити в СС ), а також спеціальне рішення Генеральної Асамблеї ООН стосовно тарифів і торгівлі, створення експертної групи з метою вивчення зв'язків між торгівлею і навколишнім середовищем.

Необхідно розробити і скоординувати ефективні заходи екологічного контролю для боротьби 3 нечесною торгівельною практикою. Це важливо зробити ще і тому, що західним бізнесменам часом вигідно позбутись брудних технологій, навіть поступившись ціною. То чи не стануть, зокрема, і українські зовнішньоторговці масовими «заготівельниками» ризикованого товару? Чи не буде цим завдано ще одного удару по довкіллю? Така небезпека дійсно є. У гонитві за валютою українські підприємці вже укладають з інофірмами угоди про захоронення шкідливих залишків, а через спільні підприємства здійснюється передислокація на територію України еклогічно небезпечних виробництв і технологій. На фоні економічних негараздів та соціально-політичної невизначеності проблеми екології витісняються на другий план. Одним з показників зниження духовних критеріїв нашого суспільства $є$ поступове звикання до екологічної небезпеки, байдужість і безвідповідальність щодо стану навколишнього середовища [124]. Отже, правила міжнародної торгівлі, які розроблялися без урахування чинників довкілля, повинні тепер бути змінені на предмет захисту останнього.

2. Вимога благоустрою навколишнього середовища має бути включена в число критеріїв, щзо використовуються міжнародними фінансовими інститутами при розгляді всіх передбачуваних грантів з фондів розвитку. Важливо при цьому враховувати і те, що деякі міжнародні фінансові інститути, створені для сприяння розвитку «третього світу» нерідко завдають їм більше шкоди, ніж користі, оскільки ігнорують екологічні наслідки великомасштабних проектів. Хоча міжнародні фінансові інститути і включають деякі екологічні критерії в умови надання позик, але рідко їх дотримуються. Тому дехто з надто нетерплячих екологів закликає до повного припинення фінансування розвиненими країнами всіх міжнародних інституцій, які не бажають чи неспроможні докорінно змінити підхід до екологічної практики. 
3. Прискорити впровадження принципу «обміну боргів на екологію» 3 метою заохочення екологічної діяльності і полегшення тягара боргу. Обмін боргів на діяльність по захисту навколишнього середовища - одна з ефективних гуманних ідей за останні десять - двадцять років. У відповідності з нею індустріальні країни списують з країн, що розвиваються, їх заборгованість, а останні забов'язуються послідовно здійснювати угоди щодо захисту ділянок навколишнього середовища на своїй території, які перебувають у небезпеці. Від цього виграють усі, бо в будь-якому разі малоймовірно, що більша частина боргів буде сплачена, а захист навколишнього середовища відповідає насущним інтересам і країн-боржників і решти світу. До того ж масоване полегшення тягара боргів, що тисне на світ, який розвивається, має важливе значення для створення стабільного суспільства, а з часом і глобальної економіки, в якій ці країни будуть невід'ємним і надійним елементом.

Непередбачуваність теперішніх угод з «третім світом» ще більш очевидна, якщо взяти до уваги, що величезна частина цього боргу утворилася внаслідок закупівлі зброї для ведення міжусобних війн, коли іноді цілі регіони поринали в атмосферу насильства і вбивств, а навколишнє середовище безжалісно деформувалося. Саме це супроводжувало, наприклад, іракське вторгнення в Кувейт у 1991 р. Запобігання таких війн (у тому числі шляхом заборони вивозу сучасних озброєнь 3 індустріальних країн) - це один з найважливіших заходів стосовно захисту навколишнього середовища, який можна здійснити.

4. Укласти міжнародні угоди, що встановлять ліміт викидів вуглекислого газу країнамучасницям, а також розвивати торгівлю ліџензіями направо викидів між країнами, які потребують більше квот, і тими, які повністю їх не використовують. Створення ринку квот на викиди вуглекислого газу в міжнародних масштабах - ще одна важлива нова ідея щодо використання ринкових механізмів для боротьби з глобальною екологічною кризою. Така угода була підписана в Кіото (Японія) в 1997 році. Вона забов'язала в першу чергу індустріальні країни обмежити щорічні викиди вуглекислого газу і затвердила механізм розподілу цих квот.

На практиці такі угоди сприятимуть більш раціональному вкладанню капіталу у виробництва, які є найефективнішою альтернативою тим виробництвам, що генерують вуглекислий газ; заміна природних видів палива відновлюваними формами енергії; розробці дієвіших методів енергозбереження i споживання, a також принципово нових підходів до основних форм життєдіяльності замість тих, що нині сприймаються як належні.

3 цією метою в кожній з держав було б доцільно створити відповідний фонд екологічної безпеки, платежі в який залежатимуть від кількості викинутого в атмосферу вуглекислого газу. Виробництво бензину, паливної нафти та інших видів палива на їі основі, природного газу та електроенергії, яка одержується в результаті спалювання природних видів палива, викличе збільшення податку на вуглекислий газ відповідно до вмісту його у виробленому паливі. Ці гроші екологічні фонди зможуть використати для субсидування екологічно ефективних технологій таких, як енергозберігаючі освітлювальні лампи або високоекономічні автомобілі.

5. Визначення величини валового національного продукту (ВНП) має бути змінено з урахування того, поліпшився чи погіршився стан навколишнього середовища. Сучасні методи розрахунку продуктивності і ВНП зовсім не враховують виснаження природних ресурсів. Уся природа вважається безмежною і безкоштовною. Деякі країни (особливо ті, що розвиваються) цілком вирубують свій дощовий ліс, викачують нафту, газ, інші корисні копалини, збільшуючи їх продажем свої прибутки, проте ніхто не вимагає від них оцінити виснаження природних багатств, або якось включити в розрахунок той факт, що через деякий час усього цього вже не буде. Потрібно позбавитись цієї екологічної сліпоти і замінити кожне помилкове формулювання у відповідних документах іншим, яке враховуватиме екологічні наслідки ринкових відносин.

6. Встановити для виробничої продукиії податок на чисту сировину, в залежності від кількості невідновлюваної чистої сировини, використаної при ї̈ виготовленні. Наприклад, паперові фабрики оподатковувались би відповідно до відсотку продукції, виробленої із щойно зрублених дерев, а не з рецикльованих пульпи і паперових відходів. У цьому разі виробники і споживачі, які сплачують податок, зажадали б податкових пільг для придбання обладнання, потрібного для рециклювання, а також ефективного збирання і використання рецикльованих матеріалів, сподіваючись на одержання прибутку.

7. Вдосконалювати методику прогнозування впливу прийнятих рімень на умови життя майбутніх поколінь. Технологічна могутність людства радикально посилила здатність видозмінювати навколишній світ на свій розсуд, що не минає безслідно. Незважаючи на це, людство і досі розраховує 
ефект своїх дій, по суті, так само, як і на початку індустріальної революції, - сподіваючись, що жоден наш вчинок не «відгукнеться» в майбутьному. Якщо колись це було можливо, то зараз подібне припущення помилкове, і формули, в яких вона втілюється, мають бути змінені. Проте реальна робота потребує стратегічного i систематичного планування. Адже щоб перейти до нової усталеної економіки, неодмінно слід почати розраховувати вплив своїх рішень на долю майбутніх поколінь, яким доведеться мати справу з їх наслідками. Тому важливо навчитися прогнозувати наслідки будьякого рішення - на десятки, а то і сотні років наперед з урахуванням чинників екобезпеки.

8. Відмовитися від фінансових заохочень екологічно згубної діяльності. Перехід до економічних норм, які сприяють безпеці, можна прискорити за допомогою конкретних заходів. Перш за все слід відмовитися від тих внутрішньодержавних і міжнародних інвестицій, що заохочують і оплачують екологічно згубну економіку (наприклад: вирубування лісів, інтенсивна експлуатація малорентабельних грунтів, всезростаюче видобування корисних копалин тощо).

По-друге, якщо механізм регулювання природокористування базувати лише на директивно встановлених нормативах і державних стандартах, які визначають гранично припустимі викиди забруднень у навколишнє середовище, санітарні норми, припустимі обсяги вирубування лісів і т. д., то таке управління буде, в певному розумінні, прихованою формою субсидування безгосподарського природокористування. Адже навіть за умови дотримання встановлених середніх «меж» викидів забруднюючих речовин підприємства вже не витрачають ніяких коштів на компенсування шкоди, заподіяної навколишньому середовищу. Ці витрати або лягають тягарем на непричетних до шкоди платників податків, або взагалі ніким не покриваються. Це ще один аргумент на користь припинення субсидіювання виснаження природних ресурсів і зростання забруднень, І вихід бачиться у зміні податкового кодексу.

9. Здійснювати політику замовлення на екологічно прийнятні замінники там, де вони конкурують зі старими, екологічно менш вигідними технологіями, з урахуванням суми витрат за час існування останніх. Наприклад, держава повинна замінити кожну освітлювальну лампу, коли та перегорить, новою лампою тривалого користування, що забезпечує таке ж освітлення, споживаючи менше електроенергії. Держава має також взяти на себе забов'язання закуповувати рецикльований папір в обсягах, які з кожним роком дедалі повніше забезпечуватимуть потреби всієї країни до тих пір, поки практично весь використовуваний папір не буде рецикльованим. Якщо вона покаже приклад у таких справах, то виробникам екодоцільних товарів буде значно легше налагодити масове виробництво їх і прорватися на ринок.

10. Держава має встановити більш жорсткі норми економії й економічності - у будівництві, промисловому виробництві, у виробництві побутових приладів, двигунів, моторів, машин і т. п. І тут важливо врахувати дію різних чинників. Хоча, наприклад, перехід до більш ефективних засобів пересування прискорюватиметься в основному податком на вуглекислий газ - і відповідними субсидіями. Підвищення економії звичайного палива багато в чому може доповнити їх. Оскільки викиди вуглекислого газу в багатьох країнах дуже великі, для їх зменшення потрібно вживати комплекс найрізноманітніших заходів.

11. Всілякому збереженню і ефективному застосуванню сировини і матеріалів повинна сприяти реформа стандартів утилізації. У цьому питанні значного прогресу досягнуто більше на місцевому рівні, державна ж політика - безнадійно відстала. Вся сфера комунального господарства дедалі більше спрямовується на екологічні аспекти, пов'язані з економікою. Комунальні підприємства i служби заохочують підприємства і організації, наприклад, до висаджування дерев, щоб якось нейтралізувати вуглекислий газ, який викидається комунальним господарством.

12. Програми висаджування дерев (із саджанців, що дбайливо виведені з урахуванням місця посадки) мають стати частиною державних програм зайнятості, в яких вимоги працевлаштування поєднується з виплатою допомоги. Причому висаджуванню дерев слід надати статус вищого пріоритету в літніх трудових програмах для підлітків.

13. Потрібно прискорити відмову від усіх хімікатів, які нищать озон, сільськогосподарські угіддя, зрештою згубно впливають наздоров'я людей. Важливо фінансувати розробку їх дійсно доброякісних замінників.

14. Держава повинна збільшити обсяг $і$ підвищити точність інформачії про екологічний вплив товарів, що виробляються, $і$ систематично доводити ї̈ до споживача. Чим більше світове співтовариство усвідомлюватиме розміри екологічної кризи, тим важливішим буде забезпечення інформацією про екологічні наслідки наших рішень. Можна примусити ринкові сили працювати на екологію, і краще це зробити, надавши занепокоєним громадянам можливість враховувати стан 
довкілля при купівлі товарів і прийняття інших економічних рішень. Але одержувана споживачами інформація має викликати довіру. Держава повинна гарантувати цілковиту достовірність інформації, наприклад, про економічність автоматики чи побутових приладів, запровадити юридичні стандарти «зелених» етикеток і т. ін. Повна інформація про те, хто є винним у заподіянні екологічної шкоди, буде ставати дедалі важливішим чинником впливу на ринкові сили, аби вони працювали на навколишнє середовище, а не проти нього.

15. Потребують докорінної зміни стимули, пільги, санкиії та обмеження екологічного спрямування. Не викликає сумніву, що найголовнішими чинниками управління природоохоронною діяльністю (інструментами політики втручання) є заохочення і пільги, які стимулюють суб'єктів конкретного сектору економіки до самостійних кроків щодо захисту середовища, а також визначають санкції і обмеження, які застосовуються за невиконання умов на одержання стимулів i пільг [10, с.371-385].

Висновки. Таким чином, деградація природного середовища має глибокі соціально-економічні корені. Природа завжди «боляче» реагує на нерозумні дії, проте ця реакція має різні часові інтервали і не завжди викликає адекватну реакцію суспільства. Проте, коли окремі кількісні порушення призводять до якісних змін, чи, точніше, до різкого зниження якості життя через руйнування природних систем, це викликає відповідну реакцію. Стає очевидним неспроможність адміністративно-правової системи і непродуктивність самої моделі суспільства споживання і його розвитку за рахунок надмірної експлуатації природних ресурсів.

Усі екологічні проблеми - і глобальні, і регіональні - тісно взаємопов'язані і можуть бути вирішені, якщо відбудуться зрушення в мисленні, і народи зосередять свої зусилля на тій системі заходів, яку пропонує стратегічна екологічна ініціатива - зміні вектору економічного розвитку. I політики, й економісти мають визнати, що майбутнє суспільства, яке хоче залишатись життєздатним, має грунтуватись на екологічних засадах, а економічна діяльність - виходити з охорони природи. Тобто потрібна зміна моральної парадигми життедіяльності і визнати, що економічним є лише екологічне.

\section{Бібліографічний список:}

1. Хилько М.І. Екологізаиія політики. К.: ВАДЕКС, 2014. 344 с.

2. Горелов А.А. Человек - гармония - природа. М.: Наука, 1990. 188 с.

3. Экологическая антология: Экологические произведения западных авторов. Сов.-амер. гуманитарная инициатива "Голубка"; Редкол.: Г. Уорнер и др. М.; Бостон, 1992. 267 с.

4. Алексеенко И.Р., Кейсевич Л.В. Последняя иивилизация? Человек. Общество. Природа. К.: Наукова думка, 1997. $411 \mathrm{c.}$

5. Кисельов М. М. Методологія екологічного синтезу: єдність людино- та природоохоронних аспектів. К.: Наукова думка, 1995. 158 с.

6. Булатов М.О. Філософія ноосфери (Філософський зміст і сучасний смисл феномена ноосфери). К.: Наукова думка, 1995. 149 с.

7. Маєр-Абіх К.М. Повстання на захист природи. Від довкілля до спільно світу. Київ: Лібра, 2004. 196 с.

8. Морен Е. Шлях. За майбутне людства. К.: Ніка, 2014. 256 с.

9. Крисаченко В.С. Екологічна культура: теорія і практика. К.: Заповіт, 1996. 352 с.

10. Гор Эл. Земля на чаме весов (экология и человеческий дух). М.: Проза, поэзия, публицистика, 1993. $432 \mathrm{c}$.

\section{References:}

1. Khylko M.I. Ekolohizatsiia polityky. K.: VADEKS, 2014. 344 p.

2. Hopelov A.A. Chelovek - harmonyia-pryroda. M.: Nauka, 1990. 188 p.

3. Ekologicheskaya antologiya: Ekologicheskiye proizvedeniya zapadnykh avtorov. Sov.-amer. gumanitarnaya initsiativa "Golubka"; Redkol.: G. Uorner i dr. M.; Boston. 1992. 267 p.

4. Alekseyenko I.R.. Keysevich L.V. Poslednyaya tsivilizatsiya? Chelovek. Obshchestvo. Priroda. K.: Naukova dumka. 1997. $411 \mathrm{p}$.

5. Kyselov M. M. Metodolohiia ekolohichnoho syntezu: ednist ludino- na prirodoohoronnih aspektiv. K.: Naukova dumka, 1995. $158 \mathrm{p}$.

6. Bulatov M. O. Filosofiia noosferi (Filosofskyi zmist i suchasnyi smysl fenomena noosferi). K.: Naukova dumka, 1995. $149 \mathrm{p}$.

7. Maier-Abikh K. M. Povstannia na zakhyst pryrody. Vid dovkillia do spilno svitu. K.: Libra, 2004. 196 p.

8. Moren E. Shliakh. Za maibutnie liudstva. K.: Nika, 2014. 256 p.

9. Krysachenko V. S. Ekolohichna kultura: teoriia i praktyka. K.: Zapovit, 1996. 352 p.

10. Gor El. Zemlya na chashe vesov (ekologiya i chelovecheskiy dukh). M.: Proza. poeziya. publitsistika. 1993. $432 \mathrm{p}$. 


\section{Khylko M. I. Ecological Crisis as a Crisis of the Existing System of Values}

It has been discovered, that the current ecological crisis has far-reaching social-economic roots, even though it is mainly caused by the crisis of spirituality. The idea of all-encompassing control over nature is a fruit of arrogance and the result of the mind being polluted by an amiss idea that nature exists solely to provide comfort to man.

The research identified one of the most significant contradictions, which, for the most part, defines the essence of the environmental issue - the contradiction between the economic progress of mankind and the regeneration capabilities of the biosphere. It has been stated that the practical orientation strategy has led to consumerism, depletion of natural resources and the overall natural degradation. Attention is drawn to the particular danger brought upon by the phenomenon of consumerism, such as: in economic terms it is viewed as dangerous because, due to being limited in resources, nature is incapable of fulfilling endless material needs of mankind in any given moment; in geopolitical terms it causes increasingly aggressive behaviour in people, nations and countries in circumstances of limited resources; in moral terms it is due to the fact that focusing on being a fashionable and prestigious consumer leads to a person losing the understanding of the importance of the integrity of nature, and, as a result, gaining a distorted perception of oneself, as a person. For people like that clean air, water, soil and forests lose any significance, because their main values are - wealth, prestige, money and other similar amenities of the material world. This is the essence of the primitive consumeristic approach to life and nature.

The research draws a conclusion that the contemporary resource limitations of mankind are caused by the influence of certain social and cultural factors that can be affected by how the public life is organized. Lofty spiritual values should somehow regulate the daily living necessities and their differentiation. Humanity needs to rethink their place in the world structure in order to view a man not as the conqueror of nature, but rather as an organic part of its structure, which would, of course, mean radically changing the values, particularly those concerning the attitude toward nature. It is crucial to realize that the increase of welfare and living conditions on its own doesn't make people happy. Modern mankind needs to review their traditional rational-pragmatic priorities, fundamentally increase the levels of morality and spirituality, and realize that in the process of using natural resources people are to gain not only the "daily bread" for our bodies, but also the "bread" for our souls. The research paper provides suggestions on the main changes to the vector of economic development, the so-called strategic environmental initiatives of humanity, that would at the same time become the bases for the shift of the moral paradigm of the mankind development, in which only the ecologically rational things would be considered economically rational.

Key words: ecological values, ecological values, biosphere, consumerism, natural resources, strategic environmental initiatives. 